\title{
Economic and productivity performance of tilapia and rohu carp polyculture systems in Bangladesh, Egypt, and Myanmar
}

Ling Yee Khor ${ }^{\mathrm{a}, *}$, Nhuong Tran ${ }^{\mathrm{b}}$, Kelvin Mashisia Shikuku ${ }^{\mathrm{b}}$, Natalia Campos ${ }^{\mathrm{a}}$, Manfred Zeller ${ }^{\mathrm{a}}$

${ }^{a}$ Hans Ruthenberg Institute, University of Hohenheim, Stuttgart, Germany. ${ }^{\mathrm{b}}$ WorldFish, Penang, Malaysia.

* Corresponding author. Tel.: +49 71145924059. Email address: lykhor@uni-hohenheim.de. 


\title{
Economic and productivity performance of tilapia and rohu carp polyculture systems in Bangladesh, Egypt, and Myanmar
}

\begin{abstract}
Polyculture of fish is a common pond-based aquaculture system practiced by small-scale producers in developing countries to improve input use efficiency, and increase productivity and profits. We conduct a cross-country comparison to examine whether the economic and productivity benefits are seen in data of 1,651 ponds from 1,307 fish farming households in three countries: Bangladesh, Egypt, and Myanmar. Among these ponds, polyculture is the prevailing system, as it is practiced in $66 \%$ of them. The surveys of these households were completed in 2019. We use propensity score matching to match the ponds based on household and pond characteristics, so that ponds are compared with other similar ponds. Results indicate that the aquaculture revenue and profit of polyculture ponds are higher than those of monoculture ponds by US\$4,993 and US\$6,985, respectively, per hectare per cycle. The increase is also observed in the systems of tilapia polyculture and rohu polyculture, which are the two most common systems among the sampled farmers. The increase for rohu polyculture at US\$7,992 in revenue and US\$9,366 in profit per hectare per cycle is higher than the increase for tilapia polyculture at US\$4,649 and US\$6,649, respectively. However, tilapia polyculture farmers save more harvested fish for household consumption, by $72 \mathrm{~kg}$ per cycle, than farmers of other systems. The higher profits for general polyculture, tilapia polyculture, and rohu polyculture are statistically significant after controlling for country-level factors and have high critical value of gamma in the Rosenbaum sensitivity analysis, indicating that these results are robust. This analysis from fish farming households complements the results from pond experiments and can help to inform decision-making in aquaculture policy and training.
\end{abstract}




\section{Introduction}

Aquaculture contributes significantly to both income and nutrition of households and the economies at the local and national levels (FAO, 2020). At the global level, a crucial transition is taking place as capture fisheries are succeeded by aquaculture (Belton and Thilsted, 2014). Capture fisheries will continue to be important, but aquaculture has proven its critical role in ensuring global food and nutrition security (FAO, 2020). Analyzing the past 20 years of aquaculture development, Naylor et al. (2021) find that inland aquaculture with freshwater fish is the sector with the largest contribution to total aquaculture volumes, rural livelihoods, and food security. Rashid et al. (2019) find that aquaculture contributes to an increase of $2.1 \%$ in income in Bangladesh and helps 18 million of the population out of poverty. Aquaculture income and production also have the potential to improve the food and nutrition security of fish farming households through an increase in fish consumption (Ahmed and Waibel, 2019; Kawarazuka and Béné, 2010; Murshed-E-Jahan and Pemsl, 2011; Pant et al., 2014; Villasante et al., 2015).

In examining the potential of aquaculture to improve vitamin A intake in Bangladesh, Fiedler et al. (2016) find that the practice of polyculture, involving the production and consumption of small indigenous species, could help reduce the prevalence of inadequate vitamin A intake. Polyculture is a sustainable aquaculture system, as it can improve water use efficiency, optimize the use of the pond area, and help to recycle nutrient (Ali et al., 2017; Dumont et al., 2013; Hisano et al., 2019; Thomas et al., 2020; Uddin et al., 2006). Results from an experimental study by Hisano et al. (2019) indicate that the average weight gain of Nile tilapia is greater in polyculture. This is similar to the findings from Thomas et al. (2020), in which the final weight and biomass gain are greater with polyculture. Our study builds on and expands the scope of previous research by analyzing the on-farm performance of aquaculture systems in three countries: Bangladesh, Egypt, and Myanmar. The analysis focuses on 
comparing the economic and productivity performance of the polyculture systems practiced by farmers in the three countries. In addition to polyculture, we also examine the effect of pond depth. A pond that is too shallow can get too hot and covered by water plants, while the sunlight cannot reach water that is too deep, which affects the oxygen production of plankton for the fish (Chakroff et al., 1984; Kapute et al., 2016).

As tilapia (Oreochromis niloticus) and rohu carp (Labeo rohita) are the two most common farmed fish among the farmers in the study area, we look at how tilapia polyculture and rohu polyculture compare with the other systems. In an analysis of the trends in aquaculture, Belton et al. (2018) refute the claim that fish harvest in global South is mainly exported to the rich countries or meant for the wealthier population in the country, as is usually observed in the early development of aquaculture. During this early stage, fish farming tends to focus on the highvalue species, such as the Indian major carps, of which rohu is the most popular species. The culture of rohu carp has high consumer preference and growth potential, making it one of the most important farmed fish species in India and other countries in the region, such as Bangladesh, Pakistan, and Myanmar (Jena, 2010). However, Belton et al. (2018) note that the trends in Bangladesh indicate that the low-value species are gaining in demand, with more tilapia being consumed in the country than rohu carp. Tilapia was initially introduced to developing countries and farmed on subsistence level to meet the dietary requirement of protein. With improvement in farming techniques, tilapia has risen to become the second most important farmed fish after carps, with Indonesia, China, and Egypt being the major producing countries (Rakocy, 2010).

The surveys for our analysis were completed by WorldFish in 2019 and the dataset comprises 1,307 mainly small-scale fish farming households operating 1,651 ponds, $73 \%$ of which have tilapia and 53\% have rohu carp as part of their production. The three countries have different preferences for farmed fish among the producers. Tilapia is the preferred choice in Egypt, rohu carp is preferred in Myanmar, while both tilapia and rohu carp are popular in Bangladesh. As the sample in our study consists of only fish farmers, the focus of analysis is on 
the comparison of on-farm aquaculture performance, such as production costs, revenue, profit, benefit-cost ratio, yield, and labor productivity. We also look at how these households with various systems differ in their fish consumption from own harvest. In order to account for the diverse characteristics of sampled households in the analysis, we use propensity score matching to match the farm households and ponds from different systems.

\section{Methodology}

Propensity score matching (PSM) by Rosenbaum and Rubin (1983) helps to reduce the selection bias when conducting causal inferences in observational studies. In the first stage, the propensity score is estimated in a binary choice model, such as probit or logit, for each pond based on a set of variables. The propensity score captures the likelihood of a pond being in a certain group:

$$
p(X)=\operatorname{Pr}[D=1 \mid X]
$$

where $p(X)$ is the propensity score and $\operatorname{Pr}[D=1 \mid X]$ is the probability that an observation is in a certain group given a set of variables, $X$. Ponds in the group (e.g., polyculture) are then matched with ponds outside of the group (e.g., monoculture) based on their propensity scores. This helps to ensure that a matching pair of ponds have similar characteristics, so that they can be compared. In this stage of estimating the propensity score, we include variables that could influence the likelihood of a pond being in a certain group with good matching quality (Caliendo and Kopeinig, 2008), such as the characteristics of household (participation in fish farming organization and loan request for the aquaculture operation), household head (age, education, and gender), and pond (size). After generating the propensity score, several methods can be used to match the ponds. Following the recommendation of Rosenbaum and Rubin (1985), we choose the caliper matching method with a caliper size of one-quarter of the standard deviation of the propensity score. 
The average treatment effect on treated (ATT) can be computed based on the difference in mean between the matched partners (Caliendo and Kopeinig, 2008):

$$
A T T=E\left(Y_{1} \mid p(X)\right)-E\left(Y_{0} \mid p(X)\right)
$$

The standard errors used in calculating the statistical significance of the ATT are estimated with bootstrapping (Lechner, 2002). We then examine the quality of matching by checking the reduction in mean bias and the likelihood in predicting the selection into a certain group. After matching, there should be no significant difference in the variables used in predicting selection between the groups being compared. We also conduct the sensitivity analysis proposed by Rosenbaum (2002) and look at the critical level of gamma $(\Gamma)$. It indicates how sensitive the results are to unobserved variables. We conduct these checks using the STATA commands pstest by Leuven and Sianesi (2003) and rbounds by Gangl (2004).

The PSM methodology has been widely used in the impact assessment literature to address the potential selection bias caused by the differences in characteristics between the farmers in a group, such as the adopters of certain technology, and those outside of the group (Gitonga et al., 2013; Khor and Feike, 2017; Lenjiso et al., 2016; Loos and Zeller, 2014; Nyumba et al., 2020). With this method, Kumar and Quisumbing (2011) find that fish production helps to raise consumption expenditure and asset accumulation in Bangladesh and Khan et al. (2012) show that community-based management has a positive impact on the income and household expenditure of fish farmers. A study by Islam et al. (2015) in the same country indicates that the integrated farming system of rice and fish increases both the farm income and the frequency of fish consumption. Alawode and Oluwatayo (2019) assess the outcome of the Fadama program in Nigeria on bridging the gap between the supply and demand of protein and find that the program has a positive impact. Results from Amankwah and Quagrainie (2019) indicate that the adoption of improved fish feed technology in Ghana increases aquaculture income and reduces poverty. Other studies that have applied this methodology include impact assessment of fish 
production in Brazil on Human Development Index (Flores and Pedroza Filho, 2019), artificial reef on fishery income in Thailand (Kantavichai et al., 2019), and the practice of shrimp-fish polyculture in Indonesia on farm income (Erwiantono et al., 2020).

\section{Data}

This analysis is based on surveys conducted in three countries: Bangladesh, Egypt, and Myanmar, using a common on-farm aquaculture performance assessment tool developed by the "Scaling systems and partnerships for accelerating the adoption of improved tilapia strains by small-scale fish farmers (SPAITS)" project implemented by WorldFish. These countries were chosen because they were identified as the focal countries of the Consultative Group on International Agricultural Research (CGIAR) Research Program on Agri-Food Fish Systems. The study sites within these countries were selected based on their importance in aquaculture or the potential for future aquaculture expansion. After the regions were identified, the survey sample was selected using a combination of stratified and random sampling procedures. Details of the survey sampling procedures applied in surveys in Bangladesh, Egypt, and Myanmar were reported in Tran et al. (2021), Shikuku et al. (2020), and Aung et al. (2021), respectively.

The selected fish farmers were then interviewed in household surveys, using a pre-designed questionnaire in Open Data Kit (ODK). The surveys were conducted from December 2018 to February 2019 in Bangladesh, from May to July 2019 in Myanmar, and from September to December 2019 in Egypt. The total sample size is 1,651 with 805 in Bangladesh, 397 in Egypt, and 449 in Myanmar. The questionnaires focused on detailed aquaculture performance data, such as pond characteristics, input and costs, labor productivity, output and revenue, how the output was used, and various household characteristics for the purpose of matching the households, such as household head characteristics, participation in fish farming organization, and loan request. The data on aquaculture performance were all based on the most recent completed fish farming cycle before the interview was conducted. These data were collected at 
the pond level. As it was not possible to split the input use by fish type in a polyculture pond, the costs and revenue in the rohu polyculture group, for example, refer to the total costs and revenue from the polyculture pond with rohu carp, and not just the costs and revenue from rohu carp alone. Financial data, such as costs and revenue, were all answered in local currency. We then converted them to US\$ using the average conversion rate of 2019 retrieved from The World Bank (2019).

In selecting the variables to match the ponds, we focus on various aspects that affect livelihood strategies (Scoones, 1998). Human capital is represented by the age, education, and gender of the household heads. Participation in fish farming organization reflects the social capital. Loan request and pond size are included to capture the financial capital. In addition, the size of the pond could also impose some natural limitations on the aquaculture systems that can be performed. As the analysis comprises fish farmers in three different countries and there could be natural factors and policy differences that affect the choice of farmers on aquaculture systems, we also check for the results after including a country-level dummy variable. Table 1 shows the summary statistics of the matching variables and the outcome variables used in the analysis. In the study area, $66 \%$ of the ponds are polyculture while the median pond depth is $1.5 \mathrm{~m}$. For the pond depth dummy variable used in the analysis, ponds with depth below the median level of $1.5 \mathrm{~m}$ are given a value of one and the designation of "shallower pond" while the other ponds receive the value of zero. As the experiment conducted by El-Sayed et al. (1996) in Egypt on tilapia production indicates that the $1 \mathrm{~m}$ and $2 \mathrm{~m}$ ponds perform the best, we also examine whether the results of our analysis change if the comparison is between ponds with depth below $1 \mathrm{~m}$ and those above. We then compare the pond depth above $2 \mathrm{~m}$ group with others.

Looking at the mean values of the three countries, the surveyed farmers of Bangladesh practice a more intensive aquaculture system, with higher costs, revenue, benefit-cost ratio, and yield than those of the other two countries. On the other hand, the farmers from Egypt keep 
Table 1

Summary statistics of variables used in propensity score matching and as outcome of the analysis.

\begin{tabular}{|c|c|c|c|c|c|c|c|c|}
\hline \multirow[b]{2}{*}{ VARIABLES } & \multicolumn{2}{|c|}{ All } & \multicolumn{2}{|c|}{ Bangladesh } & \multicolumn{2}{|c|}{ Egypt } & \multicolumn{2}{|c|}{ Myanmar } \\
\hline & Mean & $\begin{array}{l}\text { Standard } \\
\text { deviation }\end{array}$ & Mean & $\begin{array}{l}\text { Standard } \\
\text { deviation }\end{array}$ & Mean & $\begin{array}{l}\text { Standard } \\
\text { deviation }\end{array}$ & Mean & $\begin{array}{l}\text { Standard } \\
\text { deviation }\end{array}$ \\
\hline Costs of aquaculture (US\$ per hectare) & $9,770.85$ & $12,474.77$ & $12,361.54$ & $12,382.40$ & $8,636.34$ & $9,049.96$ & $6,129.20$ & $14,110.46$ \\
\hline Revenue from fish sale (US\$ per hectare) & $14,631.33$ & $61,924.92$ & $18,429.83$ & $85,476.11$ & $15,646.64$ & $10,719.64$ & $6,923.38$ & $28,695.07$ \\
\hline Profit of aquaculture (US\$ per hectare) & $4,860.48$ & $62,104.57$ & $6,068.29$ & $85,698.36$ & $7,010.30$ & $11,841.30$ & 794.19 & $29,629.79$ \\
\hline Benefit-cost ratio of aquaculture & 2.23 & 15.80 & 2.46 & 21.90 & 2.15 & 2.02 & 1.88 & 7.41 \\
\hline Fish yield (kg per hectare) & $9,780.26$ & $12,991.58$ & $11,495.66$ & $10,323.20$ & $10,357.55$ & $5,206.35$ & $6,194.35$ & $19,696.32$ \\
\hline Labor productivity (US\$ per hour) & 33.21 & 363.92 & 25.03 & 441.46 & 87.33 & 389.56 & 0.02 & 7.60 \\
\hline Harvested fish kept for consumption $(\mathrm{kg})$ & 140.99 & 551.86 & 79.13 & 640.79 & 407.45 & 576.00 & 16.30 & 78.11 \\
\hline Age of household head & 44.37 & 11.82 & 40.48 & 10.03 & 44.14 & 11.03 & 51.54 & 12.17 \\
\hline Education of household head (year) & 8.60 & 4.59 & 9.72 & 4.90 & 9.49 & 4.47 & 5.81 & 2.47 \\
\hline Gender of household head ( $1=$ female $)$ & 0.02 & 0.15 & 0.00 & 0.04 & 0.02 & 0.12 & 0.07 & 0.25 \\
\hline $\begin{array}{l}\text { Member of fish farming group past year } \\
(1=\text { yes })\end{array}$ & 0.28 & 0.45 & 0.05 & 0.21 & 0.08 & 0.27 & 0.86 & 0.35 \\
\hline Requested for loan past year $(1=$ yes $)$ & 0.31 & 0.46 & 0.24 & 0.43 & 0.02 & 0.15 & 0.68 & 0.47 \\
\hline Pond size (ha) & 1.12 & 2.07 & 0.42 & 0.54 & 3.75 & 2.84 & 0.05 & 0.08 \\
\hline Polyculture $(1=$ yes $)$ & 0.66 & 0.48 & 0.93 & 0.25 & 0.80 & 0.40 & 0.02 & 0.15 \\
\hline Monoculture with tilapia (1=yes) & 0.08 & 0.27 & 0.07 & 0.25 & 0.20 & 0.40 & 0.00 & 0.05 \\
\hline Monoculture with rohu (1=yes) & 0.11 & 0.31 & 0.00 & 0.00 & 0.00 & 0.00 & 0.40 & 0.49 \\
\hline Polyculture with tilapia (1=yes) & 0.65 & 0.48 & 0.93 & 0.25 & 0.80 & 0.40 & 0.00 & 0.05 \\
\hline Polyculture with rohu (1=yes) & 0.42 & 0.49 & 0.85 & 0.36 & 0.00 & 0.00 & 0.02 & 0.15 \\
\hline Pond depth (m) & 1.47 & 0.46 & 1.47 & 0.52 & 1.64 & 0.35 & 1.32 & 0.35 \\
\hline $\mathrm{N}$ & 1,6 & 651 & 805 & & 3 & 97 & 44 & 49 \\
\hline
\end{tabular}


more of their harvested fish for own consumption. The average pond size is the smallest in Myanmar, but a higher percentage of the surveyed households there participated in fish farming organization and requested loan for their aquaculture operation in the past year.

\section{Results and discussion}

Table 2 shows the results of the probit regression on all polyculture fish farming, tilapia polyculture, and rohu polyculture for use in propensity score matching. The sign and the

\section{Table 2}

Probit regression on polyculture fish farming.

\begin{tabular}{llll}
\hline VARIABLES & $\begin{array}{c}\text { All } \\
\text { polyculture }\end{array}$ & $\begin{array}{c}\text { Tilapia } \\
\text { polyculture }\end{array}$ & $\begin{array}{c}\text { Rohu } \\
\text { polyculture }\end{array}$ \\
\hline Age of household head & & & \\
& $-0.013^{* * *}$ & $-0.015^{* * *}$ & $-0.011^{* * *}$ \\
Education of household head (year) & $(0.004)$ & $(0.004)$ & $(0.003)$ \\
& $0.031^{* * *}$ & $0.032^{* * *}$ & $0.021^{* *}$ \\
Gender of household head (1=female) & $(0.009)$ & $(0.009)$ & $(0.008)$ \\
& $-0.796^{* *}$ & $-0.739^{* *}$ & \\
Member of fish farming group (1=yes) & $(0.325)$ & $(0.332)$ & \\
& $-1.673^{* * *}$ & $-1.755^{* * *}$ & $-1.788^{* * *}$ \\
Requested for loan in past year (1=yes) & $(0.092)$ & $(0.094)$ & $(0.102)$ \\
& $-0.449^{* * *}$ & $-0.484^{* * *}$ & -0.061 \\
Pond size (ha) & $(0.088)$ & $(0.090)$ & $(0.086)$ \\
& $0.047^{* *}$ & $0.050^{* *}$ & $-0.605^{* * *}$ \\
Sensitivity (\%) & $(0.021)$ & $(0.021)$ & $(0.041)$ \\
Specificity (\%) & & & \\
Correctly classified (\%) & 93.16 & 93.94 & 87.36 \\
Pseudo R ${ }^{2}$ & 67.84 & 68.74 & 77.54 \\
N & 84.43 & 85.10 & 81.77 \\
& 0.363 & 0.384 & 0.330 \\
\hline
\end{tabular}

Standard errors in parentheses. The gender variable is dropped for the rohu polyculture regression because all farmers within the group are male.

$$
* * * \mathrm{p}<0.01, * * \mathrm{p}<0.05,{ }^{*} \mathrm{p}<0.1
$$

statistical significance of the factors are similar for these polyculture systems. The major difference is in the pond size. Whereas polyculture is associated with bigger pond size in general, this is only observed in the polyculture with tilapia. The farmers who practice polyculture with 
rohu carp are the opposite and have smaller pond size. Table A.1 in Appendix A shows the results of probit regression on pond depth. The farmers who go for polyculture share some similarities with those who have deeper ponds. Higher education and pond size are associated with general polyculture and greater pond depth while loan request in the previous year has a

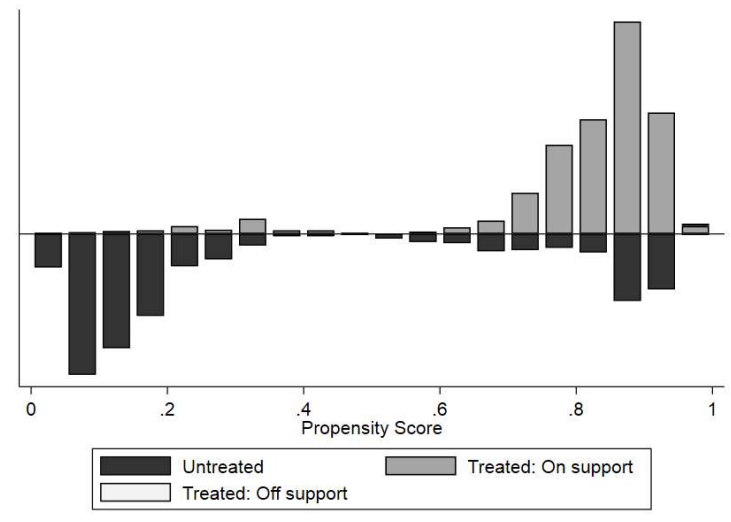

All polyculture

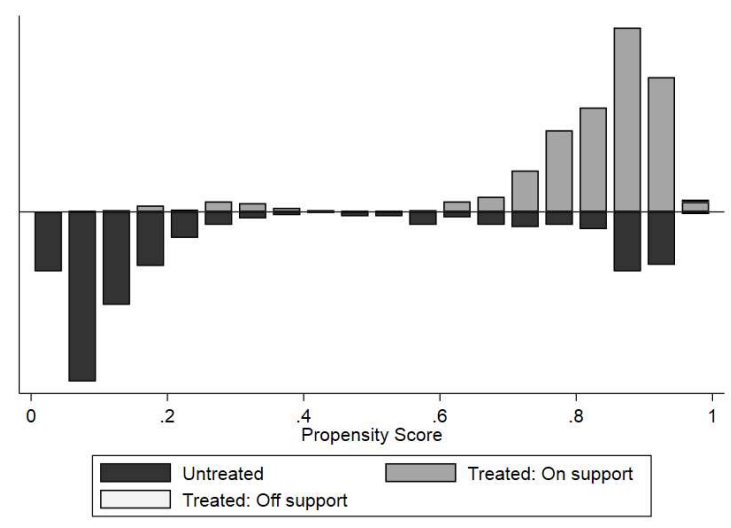

Tilapia polyculture

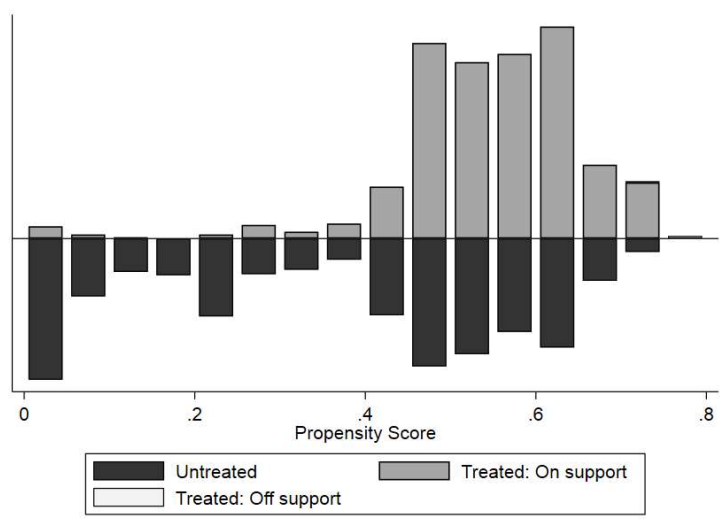

Shallower pond

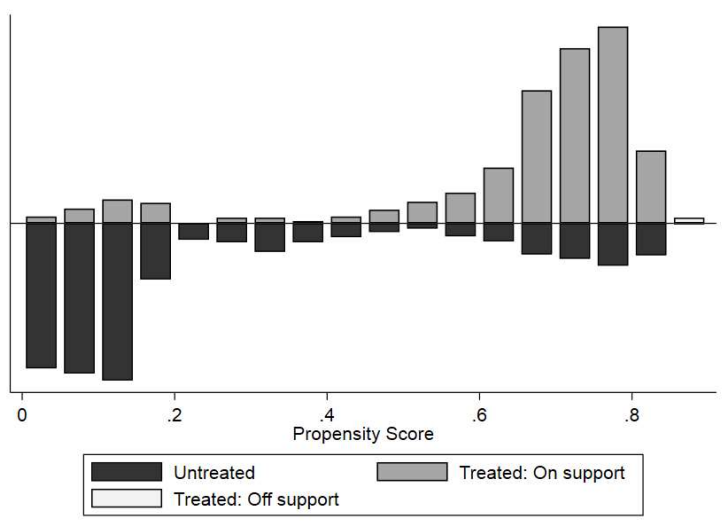

Rohu polyculture

Fig. 1. Distribution of propensity score and common support.

negative link. Difference is observed in age and gender of household heads and household's participation in fish farming organization, with all three having a statistically significant link to polyculture but only the last is associated with pond depth. 
After generating the propensity score, the ponds are matched according to their respective scores using the caliper matching method with a caliper size of one-quarter of the standard deviation of the propensity score (Rosenbaum and Rubin, 1985). Fig. 1 shows the distribution of the propensity score generated and the number of ponds that are within the common support area. The off-support cases are not included in the PSM analysis because these ponds do not have a matching pond that fulfills the criteria set in caliper matching, that is an observation

\section{Table 3}

Difference in mean before and after matching.

\begin{tabular}{lllll}
\hline \multirow{2}{*}{ VARIABLES } & \multicolumn{2}{c}{ Before matching } & \multicolumn{2}{c}{ After matching } \\
\cline { 2 - 5 } & Mean $_{\mathrm{t}}$ Mean $_{\mathrm{c}}$ Sig. & Mean $_{\mathrm{t}}$ Mean $_{\mathrm{c}}$ Sig. \\
\hline
\end{tabular}

All polyculture group:

Age of household head

Education of household head (year)

Gender of household head (1=female)

\begin{tabular}{|c|c|c|c|c|}
\hline 41.86 & 49.15 & $* * *$ & 41.87 & 42.40 \\
\hline 9.50 & 6.91 & $* * *$ & 9.48 & 9.51 \\
\hline 0.01 & 0.06 & $* * *$ & 0.01 & 0.01 \\
\hline 0.07 & 0.67 & $* * *$ & 0.07 & 0.06 \\
\hline 0.19 & 0.54 & $* * *$ & 0.19 & 0.16 \\
\hline 1.45 & 0.48 & $* * *$ & 1.40 & 1.32 \\
\hline
\end{tabular}

Participated in fish farming group (1=yes)

$\begin{array}{rrlrr}41.71 & 49.28 & * * * & 41.73 & 42.32 \\ 9.52 & 6.90 & * * * & 9.51 & 9.56 \\ 0.01 & 0.06 & * * * & 0.01 & 0.01 \\ 0.06 & 0.67 & * * * & 0.06 & 0.05 \\ 0.19 & 0.54 & * * * & 0.19 & 0.16 \\ 1.47 & 0.48 & * * * & 1.41 & 1.34\end{array}$

\section{Rohu polyculture group:}

Age of household head

Education of household head (year)

Gender of household head (1=female)

$\begin{array}{rrlrr}41.07 & 46.47 & * * * & 41.18 & 43.16 \\ 9.45 & 8.08 & * * * & 9.39 & 9.09 \\ 0.00 & 0.00 & & 0.00 & 0.00 \\ 0.06 & 0.42 & * * * & 0.06 & 0.06 \\ 0.28 & 0.33 & * * & 0.28 & 0.31 \\ 0.44 & 1.66 & * * * & 0.45 & 0.40\end{array}$

Participated in fish farming group ( $1=$ yes $)$

Requested for loan (1=yes)

Pond size (ha)

0.44

$1.66 * * *$

0.45

0.40

Mean $_{t}$ is the mean within the group. Mean ${ }_{c}$ is the mean of other observations outside the group. Sig. is the statistical significance of the difference in mean between the two groups using t-test.

$$
* * * \mathrm{p}<0.01, * * \mathrm{p}<0.05, * \mathrm{p}<0.1
$$


needs to have a matching partner with propensity score that is within one-quarter of the standard deviation of the propensity score (Rosenbaum and Rubin, 1985). In all four groups of analysis, the off-support cases are few, with between 3 and 5 cases being dropped. This amounts to less than $1 \%$ of the sample size.

Table 3 shows the difference in mean of the household and pond characteristics between those within the group (e.g., polyculture) and those outside (e.g., monoculture) before and after matching. Before matching, the difference in mean between groups is statistically significant for almost all the variables used in generating the propensity score. After matching, the number of variables showing difference in mean between groups that is statistically significant is down to one in each group. For further checks on the balance between comparison groups, the statistics of mean bias, median bias, and likelihood of selecting into a group before and after matching are illustrated in Table 4. We see that there is a big drop in the percentage of both mean bias and

\section{Table 4}

Mean bias, median bias, and likelihood of selecting into a group before and after matching.

\begin{tabular}{lccc}
\hline & Mean bias (\%) & Median bias (\%) & LR test (p-value) \\
\hline & & & \\
$\quad$ All polyculture group: & 73.3 & 61.8 & 0.000 \\
Before matching & 3.4 & 3.4 & 0.221 \\
After matching & & & \\
$\quad$ Tilapia polyculture group: & 75.3 & 63.5 & 0.000 \\
Before matching & 3.4 & 3.2 & 0.222 \\
After matching & & & \\
$\quad$ Rohu polyculture group: & 49.0 & 47.9 & 0.000 \\
Before matching & 6.9 & 6.6 & 0.012 \\
After matching & & & \\
\end{tabular}

median bias after matching. The likelihood of selecting into a group before matching is also highly significant, all with statistical significance at the $1 \%$ level. After matching, other than the rohu polyculture group, which is significant at the $5 \%$ level, the likelihood is statistically 
insignificant for the other three groups of all polyculture, tilapia polyculture, and shallower pond.

These results indicate that PSM has helped to create groups that are relatively balanced so that comparison of outcome, such as aquaculture performance, can be carried out.

\section{Table 5}

Difference in outcome variables between groups.

\begin{tabular}{lllll}
\hline VARIABLES & Mean $_{\mathrm{t}} \quad$ Mean $_{\mathrm{c}} \quad$ Diff. & $\begin{array}{c}\text { Standard } \\
\text { error }\end{array}$ \\
\hline
\end{tabular}

All polyculture group:

Costs of aquaculture (US\$ / ha)

Revenue from fish sale (US\$ / ha)

Profit of aquaculture (US\$ / ha)

Benefit-cost ratio of aquaculture

Fish yield ( $\mathrm{kg} / \mathrm{ha})$

Labor productivity (US\$ / hour)

Harvested fish kept for consumption $(\mathrm{kg})$ $\mathrm{N}$

Tilapia polyculture group:

Costs of aquaculture (US\$ / ha)

Revenue from fish sale (US\$ / ha)

Profit of aquaculture (US\$ / ha)

Benefit-cost ratio of aquaculture

Fish yield (kg / ha)

Labor productivity (US\$ / hour)

Harvested fish kept for consumption $(\mathrm{kg})$ $\mathrm{N}$

Rohu polyculture group:

Costs of aquaculture (US\$ / ha)

Revenue from fish sale (US\$ / ha)

Profit of aquaculture (US\$ / ha)

Benefit-cost ratio of aquaculture

Fish yield (kg / ha)

Labor productivity (US\$ / hour)

Harvested fish kept for consumption $(\mathrm{kg})$

$\mathrm{N}$

$\begin{array}{rrr}11038.71 & 10807.22 & 231.49 \\ 18054.27 & 13624.76 & 4429.51 \\ 7015.57 & 2817.54 & 4198.02 \\ 2.44 & 2.00 & 0.44 \\ 11415.01 & 9074.43 & 2340.57 \\ 39.67 & 63.70 & -24.03 \\ 187.32 & 115.72 & 71.60 \\ 1,078 & 569 & \end{array}$

1202.63

2696.72

2899.89

0.64

749.14

18.05

$24.43 * * *$

$\begin{array}{rrrrl}11058.25 & 10900.46 & 157.80 & 1229.36 & \\ 17713.04 & 14142.39 & 3570.66 & 2637.02 & \\ 6654.79 & 3241.93 & 3412.86 & 2911.14 & \\ 2.40 & 2.04 & 0.36 & 0.65 & \\ 11195.57 & 9383.17 & 1812.40 & 780.04 & * * \\ 39.96 & 64.49 & -24.52 & 18.24 & \\ 188.86 & 117.18 & 71.69 & 24.65 & * * * \\ 1,068 & 579 & & & \end{array}$

$\begin{array}{crrrl}12385.99 & 9650.66 & 2735.33 & 983.12 & * * * \\ 20026.35 & 11302.03 & 8724.31 & 3639.45 & * * \\ 7640.35 & 1651.37 & 5988.98 & 3879.45 & \\ 2.65 & 1.71 & 0.94 & 0.92 & \\ 12194.20 & 7749.95 & 4444.24 & 776.51 & * * * \\ 28.83 & 17.16 & 11.66 & 20.70 & \\ 76.71 & 57.08 & 19.63 & 23.08 & \\ 691 & 917 & & & \end{array}$

Mean $_{t}$ is the mean within the group. Mean ${ }_{c}$ is the mean of other observations outside the group. Standard error is estimated using bootstrapping with 500 repetitions. Sig. is the statistical significance of the difference in mean between the two groups using t-test.

$$
* * * \mathrm{p}<0.01, * * \mathrm{p}<0.05,{ }^{*} \mathrm{p}<0.1
$$


The outcome variables in this analysis of costs, revenue, profit, benefit-cost ratio, yield, labor productivity, and harvest kept for own consumption are all based on the most recent completed fish farming cycle before the household survey. The PSM results from comparison of outcome variables between groups are shown in Table 5 for the analysis of polyculture systems. Results from analysis of pond depth can be found in Appendix A. Polyculture as a whole produces a higher yield and farmers save more harvested fish for own consumption. The higher yield is also observed in both tilapia polyculture and rohu polyculture. While farmers of tilapia polyculture save more harvest for household consumption, the farmers of rohu polyculture receive higher revenue from fish sale.

As fish farmers from different countries could face different biophysical factors and policy differences that affect their choice of aquaculture systems, we examine the results after including a country-level dummy variable to capture the country effect. In addition, the results could be sensitive to unobserved variables that are not in the analysis. Therefore, we also consider the critical level of gamma $(\Gamma)$ from sensitivity analysis proposed by Rosenbaum (2002). Table 6 shows the results after accounting for the country-level effect and the corresponding level of $\Gamma$. From the list of outcome variables that are statistically significant, the results for profit are the most robust with the critical level of gamma being greater than 2 in all three groups of general polyculture, tilapia polyculture, and rohu polyculture. Their results are less likely to be affected by the inclusion of unobserved variables were they to be available. The increase in revenue is US $\$ 4,993$ per hectare per cycle and the increase in profit is US\$6,985 per hectare per cycle for the polyculture system as a whole. Statistical significance is also observed for fish yield and fish harvest kept for own consumption, which is higher by $1,854 \mathrm{~kg}$ per hectare per cycle and $74 \mathrm{~kg}$ per cycle, respectively, for the polyculture ponds. In other studies of polyculture, Ali et al. (2017) show that polyculture leads to higher combined yield in terms of the total weight of harvest per hectare. Another study in Bangladesh by Tran et al. (2021) finds that polyculture produces 
greater revenue and profit. Research in Tanzania by Shoko et al. (2016) also indicates that polyculture is more profitable, in addition to having higher weight gain and yield.

\section{Table 6}

Results after including a country-level dummy variable and the corresponding critical level of gamma $(\Gamma)$ from sensitivity analysis.

VARIABLES Diff. Sig. Critical level of gamma

All polyculture group:

Costs of aquaculture (US\$ / ha)

Revenue from fish sale (US\$ / ha)

Profit of aquaculture (US\$ / ha)

Benefit-cost ratio of aquaculture

Fish yield ( $\mathrm{kg} / \mathrm{ha})$

Labor productivity (US\$ / hour)

Harvested fish kept for consumption $(\mathrm{kg})$

$\begin{array}{rlr}-1991.81 & & >2.00 \\ 4993.10 & * & 1.05 \\ 6984.91 & * * & >2.00 \\ 0.72 & & 1.00 \\ 1853.54 & * * & 1.05 \\ -6.79 & & >2.00 \\ 74.21 & * & 1.00\end{array}$

Tilapia polyculture group:

Costs of aquaculture (US\$ / ha)

Revenue from fish sale (US\$ / ha)

Profit of aquaculture (US\$ / ha)

Benefit-cost ratio of aquaculture

Fish yield ( $\mathrm{kg} / \mathrm{ha})$

Labor productivity (US\$ / hour)

Harvested fish kept for consumption $(\mathrm{kg})$

$\begin{array}{rlr}-2000.39 & & >2.00 \\ 4648.89 & * & 1.15 \\ 6649.28 & * * & >2.00 \\ 0.68 & & 1.00 \\ 1589.80 & * * & 1.05 \\ -9.29 & & >2.00 \\ 72.36 & * & 1.00\end{array}$

\section{Rohu polyculture group:}

Costs of aquaculture (US\$ / ha)

Revenue from fish sale (US\$ / ha)

Profit of aquaculture (US\$ / ha)

$-1374.40$

1.80

$7991.80 * * \quad 1.35$

Benefit-cost ratio of aquaculture

$9366.20 * *$

$>2.00$

Fish yield ( $\mathrm{kg} / \mathrm{ha})$

$1.04 \quad 1.00$

Labor productivity (US\$ / hour)

$3112.14 * * * \quad 1.25$

Harvested fish kept for consumption $(\mathrm{kg})$

$28.06 \quad 1.95$

$-44.84>2.00$

Diff. is the difference in mean of the outcome variables between the two groups. Sig. is the statistical significance of the difference in mean using t-test. Standard error used in the t-test is estimated using bootstrapping with 500 repetitions.

$$
* * * \mathrm{p}<0.01, * * \mathrm{p}<0.05, * \mathrm{p}<0.1
$$

Looking at the analysis of polyculture by dominant fish species (tilapia and rohu carp), there are similarities to the analysis of polyculture as a whole. Aquaculture revenue, profit, and fish yield are all higher for both tilapia polyculture and rohu polyculture. Even though these two 
polyculture systems produce higher revenue and profit when compared with the other systems, the increase in rohu polyculture is greater than that in tilapia polyculture. The revenue and profit go up by US\$7,992 and US\$9,366, respectively, per hectare per cycle for rohu polyculture, while the corresponding increase for tilapia polyculture is US\$4,649 in revenue and US\$6,649 in profit. The higher revenue and profit for rohu polyculture could be due to the Indian major carps being high-value species and rohu is the most popular species within this group (Belton et al., 2018). In our study area, the mean price that farmers receive for selling the rohu harvest ranges from US\$1.30 to US\$3.60 per $\mathrm{kg}$. In comparison, the range of mean price for selling the tilapia harvest is between US\$1.00 and US\$1.40 per kg. Tilapia was farmed in developing countries mainly for subsistence initially. Even though its importance in commercial aquaculture has seen a major rise and it has become the second most important farmed fish after carps (Rakocy, 2010), tilapia remains an important choice for polyculture farmers in the study area who want to keep more harvest for household consumption, with a statistically significant difference of $72 \mathrm{~kg}$ per cycle compared with ponds of other systems. On the other hand, the difference between rohu polyculture and the others is statistically insignificant. These results underscore the importance of tilapia in supplementing the dietary needs of fish farmers in the study area.

Comparing the farmers with pond depth below the median level of $1.5 \mathrm{~m}$, we find that ponds with shallower depth do not show any significant difference in on-farm performance after accounting for the country-level effect. In addition to the median, Table A.5 in Appendix A shows the results of comparison between the ponds with depth below $1 \mathrm{~m}$ and those above. The same analysis is then repeated with the group of ponds with depth above $2 \mathrm{~m}$. We see that the shallowest ponds (less than $1 \mathrm{~m}$ ) produce lower revenue and the farmers also keep less of their harvest for own consumption. These are statistically significant after including the country-level dummy and they also have a high critical level of gamma in the sensitivity analysis, indicating that the results are robust and less sensitive to bias caused by unobserved variables. If we 
compare the ponds with depth above $2 \mathrm{~m}$ and those below, we see that the difference between groups is statistically insignificant in all outcome variables. In an experiment conducted by ElSayed et al. (1996) in Egypt with Nile tilapia stocked in ponds of different depth levels: $0.5 \mathrm{~m}$, $1 \mathrm{~m}, 2 \mathrm{~m}$, and $3 \mathrm{~m}$, the authors find that the $0.5 \mathrm{~m}$ pond performs the worst in growth rate, final weight, and mortality rate, while the $1 \mathrm{~m}$ and $2 \mathrm{~m}$ ponds perform better than the others. The results are also in line with the recommendations of pond depth between $0.75 \mathrm{~m}$ and $2 \mathrm{~m}$ by Chakroff et al. (1984) for most pond fish. In another growth experiment with Nile tilapia, Szyper and Hopkins (1993) show that there is no significant difference in yield between the $0.9 \mathrm{~m}$ and $1.5 \mathrm{~m}$ ponds. In addition to the performance indicators that we examine, results from other studies indicate that pond depth increases organic matter and salinity (Rana et al., 2017) and it has an effect on the fat and protein contents of fish (Ali et al., 2006).

Some limitations about our study include the sampled farmers were randomly chosen from specific regions, which were identified by WorldFish due to the importance or potential of these regions in aquaculture. They are not nationally representative datasets of the three countries in the study. If such datasets were to be available in the future, it would be good to conduct similar analysis to ascertain whether the findings in this research apply to these countries as a whole. In a study that involves multiple countries, there are country-level factors that could affect the outcomes. We minimize the bias caused by these factors by checking the results after including the country-level dummy variable in the analysis. This helps to account for the factors that are constant within a country, such as the national level aquaculture policy or macroclimate. However, it does not account for factors that vary within a country, such as the local weather patterns.

We use PSM to match the ponds to ensure that the pond and household characteristics are similar for the ponds being compared. We can only match them based on the factors that are available in the dataset, such as household head characteristics, participation in fish farming organization, loan request for aquaculture operations, and pond size. These farmers could also 
differ in other factors that are unobserved, such as the motivation and ability of farmers. We cannot match based on these factors, as these data are not available. Therefore, we do not know whether the farmers and ponds being compared are balanced in these factors. It is not possible to tell whether the results will remain the same if these unobserved factors were to be available and included in the analysis. We conduct Rosenbaum sensitivity analysis to examine how robust the findings are to unobserved factors. When interpreting the results, we need to bear in mind that the results with low critical level of gamma are less robust.

The comparison of fish farming systems tends to focus on the on-farm performance indicators alone and less on the other aspects, such as the food and nutrition security of fish farming households. We include the outcome variable of harvest saved for household consumption in this analysis and find that the polyculture farmers, especially the tilapia polyculture farmers, keep more of their harvested fish for own consumption. This is important for nutrition security, as fish is a rich source of both macro- and micronutrients. Looking at the consumption from harvested fish does not provide the full picture, as these households could also supplement their harvest with fish purchased from the market. Therefore, it would be good to analyze how the different aquaculture systems affect food and nutrition security when there are more detailed food consumption data for fish farming households.

\section{Conclusion}

This article compares the polyculture systems of mainly small-scale fish farmers in three different countries, Bangladesh, Egypt, and Myanmar, focusing on assessing economic and productivity performance of polyculture systems with tilapia and rohu carp as dominant species. In addition, we also examine the choice of these farmers in the amount of harvested fish to keep for household consumption. In order to account for the difference in characteristics of fish farmers, which could also affect the outcome variables and lead to biased results, we use propensity score matching to match the ponds in a group (e.g., polyculture) with those outside 
the group (e.g., monoculture) before conducting the comparison. This ensures that ponds and farmers are compared with others who have relatively similar characteristics. As the farmers are located in three countries and there could be biophysical or political factors that affect the outcome variables differently, we also examine the findings after including a country-level dummy variable to control for these effects. In addition, we use Rosenbaum bounds to check for the sensitivity of results to unobserved variables.

The analysis shows that polyculture ponds produce higher aquaculture revenue and profit than monoculture ponds by US $\$ 4,993$ and US $\$ 6,985$, respectively, per hectare per cycle. The polyculture farmers also keep more of their harvested fish for household consumption by $74 \mathrm{~kg}$ per cycle. The increase in revenue and profit is also observed when we focus on tilapia polyculture and rohu polyculture, which are the two most common systems in the study area. The increase for rohu polyculture is at US\$7,992 in revenue and US\$9,366 in profit per hectare per cycle. It is higher than the US\$4,649 and US\$6,649, respectively, for tilapia polyculture. However, farmers of tilapia polyculture keep $72 \mathrm{~kg}$ per cycle more of harvest for own consumption, while the difference in this aspect between rohu polyculture and other systems is not statistically significant. In terms of pond depth, shallower ponds with depth below $1 \mathrm{~m}$ produce lower revenue by US\$5,412 per hectare per cycle. The amount of fish harvest that the farmers keep for own consumption is also lower by $43 \mathrm{~kg}$ per cycle. These findings are statistically significant after accounting for the country-level factors. The results of difference in profit also have high critical value of gamma in the Rosenbaum sensitivity analysis, indicating that the findings for this on-farm performance measure is robust. These cross-country data suggest that the polyculture system has the potential to increase the profit of farmers. They complement the results from pond experiments that have illustrated the benefits of increased yield in polyculture and can be taken into consideration when designing policy and training modules for small-scale fish farmers in developing countries. 


\section{Acknowledgements}

This research is a contribution to the Consultative Group on International Agricultural Research (CGIAR) Research Program on Fish Agri-Food Systems (FISH). Funding support to the study was provided by the German Federal Ministry for Economic Cooperation and Development (BMZ), on a project titled "Scaling systems and partnerships for accelerating the adoption of improved tilapia strains by small-scale fish farmers (SPAITS)" [grant number 81219436]. Funding for data collection in Bangladesh was provided by USAID's Feed the Future "Bangladesh Aquaculture Activity (BAA)" [grant number AEC10423]. Funding for data collection in Egypt was provided by Skretting. The views expressed in this document cannot be taken to reflect the official opinions of these organizations.

\section{References}

Ahmed, B. N., Waibel, H., 2019. The role of homestead fish ponds for household nutrition security in Bangladesh. Food Security, 11(4):835-854.

Alawode, O., Oluwatayo, I., 2019. Development outcomes of Fadama III among fish farmers in Nigeria: Evidence from Lagos state. Evaluation and Program Planning, 75:10-19.

Ali, M., Iqbal, F., Salam, A., Sial, F., Athar, M., 2006. Comparative study of body composition of four fish species in relation to pond depth. International Journal of Environmental Science \& Technology, 2(4):359-364.

Ali, M., Islam, M., Begum, N., Suravi, I., Mia, M., Kashem, M., 2017. Effect of monoculture and polyculture systems on growth and production of fishes in seasonal waterbodies of Haor villages, Sunamganj district. Journal of Scientific Research, 9(3):307-316.

Amankwah, A., Quagrainie, K. K., 2019. Aquaculture feed technology adoption and smallholder household welfare in Ghana. Journal of the World Aquaculture Society, 50(4):827-841. 
Aung, Y. M., Khor, L. Y., Tran, N., Akester, M., Zeller, M., 2021. The impact of sustainable aquaculture technologies on the welfare of small-scale fish farming households in Myanmar. Aquaculture Economics \& Management. Advance online publication.

Belton, B., Bush, S. R., Little, D. C., 2018. Not just for the wealthy: Rethinking farmed fish consumption in the global South. Global Food Security, 16:85-92.

Belton, B., Thilsted, S. H., 2014. Fisheries in transition: Food and nutrition security implications for the global South. Global Food Security, 3(1):59-66.

Caliendo, M., Kopeinig, S., 2008. Some practical guidance for the implementation of propensity score matching. Journal of Economic Surveys, 22(1):31-72.

Chakroff, M., Koster, J., Druben, L., 1984. Appropriate technologies for development:

Freshwater fish pond culture and management. Number 36 in Peace Corps (U.S.), Information Collection and Exchange, Volunteers in Technical Assistance. The Corps.

Dumont, B., Fortun-Lamothe, L., Jouven, M., Thomas, M., Tichit, M., 2013. Prospects from agroecology and industrial ecology for animal production in the 21 st century. Animal, 7(6):1028-1043.

El-Sayed, A.-F., El-Ghobashy, A., Al-Amoudi, M., 1996. Effects of pond depth and water temperature on the growth, mortality and body composition of Nile tilapia, Oreochromis niloticus (1.). Aquaculture Research, 27(9):681-687.

Erwiantono, Darmansyah, O., Saleha, Q., Zulkarnain, Sulistianto, E., Fahrizal, W., Maryanto, F., Susilo, H., 2020. Impact of shrimp-fish polyculture practices on small-scale farmers' income in Indonesia. Aquaculture, Aquarium, Conservation \& Legislation, 13(6):34073419.

FAO, 2020. The state of world fisheries and aquaculture 2020: Sustainability in action. Food and Agriculture Organization of the United Nations. 
Fiedler, J. L., Lividini, K., Drummond, E., Thilsted, S. H., 2016. Strengthening the contribution of aquaculture to food and nutrition security: The potential of a vitamin Arich, small fish in Bangladesh. Aquaculture, 452:291-303.

Flores, R. M. V., Pedroza Filho, M. X., 2019. Measuring the impact of fish farming on regional development of poor cities: A case study on Ceará state, Brazil. Journal of Applied Aquaculture, 31(4):356-366.

Gangl, M., 2004. RBOUNDS: Stata module to perform Rosenbaum sensitivity analysis for average treatment effects on the treated. Statistical Software Components, Boston College Department of Economics.

Gitonga, Z. M., De Groote, H., Kassie, M., Tefera, T., 2013. Impact of metal silos on households' maize storage, storage losses and food security: An application of a propensity score matching. Food Policy, 43:44-55.

Hisano, H., Barbosa, P. T., Hayd, L. A., Mattioli, C. C., 2019. Evaluation of Nile tilapia in monoculture and polyculture with giant freshwater prawn in biofloc technology system and in recirculation aquaculture system. International Aquatic Research, 11(4):335-346.

Islam, A. H. M. S., Barman, B. K., Murshed-e Jahan, K., 2015. Adoption and impact of integrated rice-fish farming system in Bangladesh. Aquaculture, 447:76-85.

Jena, J. K., 2010. Cultured aquatic species information programme: Labeo rohita. In Cultured Aquatic Species Fact Sheets. Food and Agriculture Organization (FAO).

Kantavichai, R., Mekhora, T., Ganmanee, M., Thongsamui, A., Pornratanachotsakul, M., 2019. Small-scale fishery income impact from artificial reefs in Lang Suan district, Chumphon province, Thailand. Environment, Development and Sustainability, 21(3):1519-1531.

Kapute, F., Valeta, J., Likongwe, J., Kang’ombe, J., Nagoli, J., Mbamba, D., 2016. Growth performance of three tilapia fish species raised at varied pond sizes and water depths. International Journal of Fisheries and Aquaculture, 8(8):81-86. 
Kawarazuka, N., Béné, C., 2010. Linking small-scale fisheries and aquaculture to household nutritional security: An overview. Food Security, 2(4):343-357.

Khan, M. A., Alam, M. F., Islam, K. J., 2012. The impact of co-management on household income and expenditure: An empirical analysis of common property fishery resource management in Bangladesh. Ocean \& Coastal Management, 65:67-78.

Khor, L. Y., Feike, T., 2017. Economic sustainability of irrigation practices in arid cotton production. Water Resources and Economics, 20:40-52.

Kumar, N., Quisumbing, A. R., 2011. Access, adoption, and diffusion: Understanding the long-term impacts of improved vegetable and fish technologies in Bangladesh. Journal of Development Effectiveness, 3(2):193-219.

Lechner, M., 2002. Some practical issues in the evaluation of heterogeneous labour market programmes by matching methods. Journal of the Royal Statistical Society: Series A (Statistics in Society), 165(1):59-82.

Lenjiso, B. M., Smits, J., Ruben, R., 2016. Transforming gender relations through the market: Smallholder milk market participation and women's intra-household bargaining power in Ethiopia. The Journal of Development Studies, 52(7):1002-1018.

Leuven, E., Sianesi, B., 2003. PSMATCH2: Stata module to perform full Mahalanobis and propensity score matching, common support graphing, and covariate imbalance testing. Statistical Software Components, Boston College Department of Economics.

Loos, T. K., Zeller, M., 2014. Milk sales and dietary diversity among the Maasai. Agricultural Economics, 45(S1):77-90.

Murshed-E-Jahan, K., Pemsl, D. E., 2011. The impact of integrated aquaculture-agriculture on small-scale farm sustainability and farmers' livelihoods: experience from Bangladesh. Agricultural Systems, 104(5):392-402. 
Naylor, R. L., Hardy, R. W., Buschmann, A. H., Bush, S. R., Cao, L., Klinger, D. H., Little, D. C., Lubchenco, J., Shumway, S. E., Troell, M., 2021. A 20-year retrospective review of global aquaculture. Nature, 591(7851):551-563.

Nyumba, T. O., Emenye, O. E., Leader-Williams, N., 2020. Assessing impacts of humanelephant conflict on human wellbeing: An empirical analysis of communities living with elephants around Maasai Mara national reserve in Kenya. PloS One, 15(9):e0239545.

Pant, J., Barman, B. K., Murshed-E-Jahan, K., Belton, B., Beveridge, M., 2014. Can aquaculture benefit the extreme poor? A case study of landless and socially marginalized Adivasi (ethnic) communities in Bangladesh. Aquaculture, 418:1-10.

Rakocy, J. E., 2010. Cultured aquatic species information programme. Oreochromis niloticus. In Cultured Aquatic Species Fact Sheets. Food and Agriculture Organization (FAO).

Rana, M. E. U., Hossain, S., Tapader, M. A., Hossain, M. B., Sarker, B. S., 2017. Effects of pond age and depth on bottom soil nutrients, $\mathrm{pH}$ and salinity in commercial aquaculture farm. World, 9(4):25-30.

Rashid, S., Minot, N., Lemma, S., 2019. Does a "blue revolution" help the poor? Evidence from Bangladesh. Agricultural Economics, 50(2):139-150.

Rosenbaum, P. R., 2002. Observational Studies. Springer New York, New York, NY.

Rosenbaum, P. R., Rubin, D. B., 1983. The central role of the propensity score in observational studies for causal effects. Biometrika, 70(1):41-55.

Rosenbaum, P. R., Rubin, D. B., 1985. Constructing a control group using multivariate matched sampling methods that incorporate the propensity score. The American Statistician, 39(1):33-38.

Scoones, I., 1998. Sustainable rural livelihoods: A framework for analysis. Working paper no. 72, Institute of Development Studies, Brighton, United Kingdom.

Shikuku, K., Tran, N., Henriksson, P., Nasr-Allah, A., Rossignoli, C., Roem, A., Badr, A., Cheong, K., Sbaay, A., 2020. A baseline integrated assessment of aquaculture systems 
performance in Egypt. Technical report, WorldFish.

Shoko, A. P., Limbu, S. M., Mrosso, H. D. J., Mkenda, A. F., Mgaya, Y. D., 2016. Effect of stocking density on growth, production and economic benefits of mixed sex Nile tilapia (Oreochromis niloticus) and African sharptooth catfish (Clarias gariepinus) in polyculture and monoculture. Aquaculture Research, 47(1):36-50.

Szyper, J., Hopkins, K., 1993. Effects of pond depth and mechanical mixing on production of Oreochromis niloticus in manured earthen ponds. In The Third International Symposium on Tilapia in Aquaculture.

The World Bank, 2019. Official exchange rate (LCU per US\$, period average). Retrieved from https://data.worldbank.org/indicator/PA.NUS.FCRF.

Thomas, M., Lecocq, T., Abregal, C., Nahon, S., Aubin, J., Jaeger, C., Wilfart, A., Schaeffer, L., Ledore, Y., Puillet, L., Pasquet, A., 2020. The effects of polyculture on behaviour and production of pikeperch in recirculation systems. Aquaculture Reports, 17:100333.

Tran, N., Shikuku, K. M., Rossignoli, C. M., Barman, B. K., Cheong, K. C., Ali, M. S., Benzie, J. A., 2021. Growth, yield and profitability of genetically improved farmed tilapia (gift) and non-gift strains in Bangladesh. Aquaculture, 536:736486.

Uddin, S., Ekram-Ul-Azim, M., Wahab, A., Verdegem, M. C., 2006. The potential of mixed culture of genetically improved farmed tilapia (Oreochromis niloticus) and freshwater giant prawn (Macrobrachium rosenbergii) in periphyton-based systems. Aquaculture Research, 37(3):241-247.

Villasante, S., Rodriguez, S. R., Molares, Y., Martinez, M., Remiro, J., Garcia-Diez, C., Lahoz, C., Omar, I., Bechardas, M., Elago, P., Ekandjo, M., Saisai, M., Awity, L., 2015. Are provisioning ecosystem services from rural aquaculture contributing to reduce hunger in Africa? Ecosystem Services, 16:365-377. 


\section{Appendix A. Tables}

\section{Table A.1}

Probit regression on pond depth.

\begin{tabular}{lc}
\hline VARIABLES & Shallower pond \\
\hline & \\
Age of household head & -0.000 \\
& $(0.003)$ \\
Education of household head (year) & $-0.016^{* *}$ \\
& $(0.008)$ \\
Gender of household head (1=female) & 0.214 \\
& $(0.223)$ \\
Member of fish farming group (1=yes) & $-0.264^{* * *}$ \\
& $(0.086)$ \\
Requested for loan in past year (1=yes) & $0.344^{* * *}$ \\
& $(0.076)$ \\
Pond size (ha) & $-0.433^{* * *}$ \\
& $(0.035)$ \\
Sensitivity (\%) & 69.86 \\
Specificity (\%) & 63.12 \\
Correctly classified (\%) & 66.14 \\
Pseudo ${ }^{2}$ & 0.148 \\
Observations & 1,651
\end{tabular}

Standard errors in parentheses.

$* * * \mathrm{p}<0.01, * * \mathrm{p}<0.05, * \mathrm{p}<0.1$ 
Table A.2

Difference in mean before and after matching for pond depth.

\begin{tabular}{lccc}
\hline \multirow{2}{*}{ VARIABLES } & \multicolumn{2}{c}{ Before matching } & After matching \\
\cline { 2 - 4 } & Mean $_{\mathrm{t}}$ Mean $_{\mathrm{c}}$ Sig. $\quad$ Mean $_{\mathrm{t}}$ Mean $_{\mathrm{c}}$ Sig. \\
\hline
\end{tabular}

Shallower pond group:

Age of household head

Education of household head (year)

44.63

44.16

$44.60 \quad 44.55$

Gender of household head (1=female)

8.11

$9.00 * * *$

$8.12 \quad 8.26$

$\begin{array}{llll}0.03 & 0.02 & 0.03 & 0.03\end{array}$

Participated in fish farming group (1=yes)

0.32

$0.24 * * *$

$0.33 \quad 0.34$

Requested for loan (1=yes)

0.42

0.22

$0.42 \quad 0.42$

Pond size (ha)

0.33

$1.76 * * *$

$0.34 \quad 0.35$

Mean $_{t}$ is the mean within the group. Mean ${ }_{c}$ is the mean of other observations outside the group. Sig. is the statistical significance of the difference in mean between the two groups using t-test.

$$
* * * \mathrm{p}<0.01, * * \mathrm{p}<0.05, * \mathrm{p}<0.1
$$

\section{Table A.3}

Mean bias, median bias, and likelihood of selecting into a group before and after matching for pond depth.

$$
\text { Mean bias (\%) Median bias (\%) LR test (p-value) }
$$

Shallower pond group:

$\begin{array}{lrrr}\text { Before matching } & 28.8 & 19.5 & 0.000 \\ \text { After matching } & 1.2 & 0.7 & 0.988\end{array}$


Table A.4

Difference in outcome variables between groups for pond depth.

\begin{tabular}{lrrrrr}
\hline VARIABLES & Mean $_{\mathrm{t}}$ & Mean $_{\mathrm{c}}$ & Diff. & $\begin{array}{c}\text { Standard } \\
\text { error }\end{array}$ & Sig. \\
\hline \multicolumn{1}{c}{ Shallower pond group: } & & & & & \\
Costs of aquaculture (US\$ / ha) & 9446.80 & 10934.33 & -1487.53 & 762.13 & $*$ \\
Revenue from fish sale (US\$ / ha) & 12070.09 & 17418.07 & -5347.98 & 4513.37 & \\
Profit of aquaculture (US\$ / ha) & 2623.28 & 6483.73 & -3860.45 & 4380.16 \\
Benefit-cost ratio of aquaculture & 1.89 & 2.67 & -0.78 & 1.11 \\
Fish yield (kg / ha) & 9399.18 & 9868.43 & -469.24 & 766.73 \\
Labor productivity (US\$ / hour) & 8.27 & 15.11 & -6.84 & 11.95 \\
Harvested fish kept for consumption (kg) & 50.27 & 52.07 & -1.79 & 17.74 \\
N & 737 & 911 & & & \\
& & & & &
\end{tabular}

Mean $_{t}$ is the mean within the group. Mean ${ }_{c}$ is the mean of other observations outside the group. Standard error is estimated using bootstrapping with 500 repetitions. Sig. is the statistical significance of the difference in mean between the two groups using t-test.

$$
* * * \mathrm{p}<0.01, * * \mathrm{p}<0.05, * \mathrm{p}<0.1
$$




\section{Table A.5}

Results of various pond depth groups after including a country-level dummy variable and the corresponding critical level of gamma $(\Gamma)$ from sensitivity analysis.

\begin{tabular}{lll} 
VARIABLES Diff. Sig. Critical level of gamma \\
\hline
\end{tabular}

Shallowest pond group $(<1 \mathrm{~m})$ :

Costs of aquaculture (US\$ / ha)

Revenue from fish sale (US\$ / ha)

Profit of aquaculture (US\$ / ha)

Benefit-cost ratio of aquaculture

Fish yield (kg / ha)

Labor productivity (US\$ / hour)

Harvested fish kept for consumption $(\mathrm{kg})$

Shallower pond group (< median, $1.5 \mathrm{~m})$ :

Costs of aquaculture (US\$ / ha)

Revenue from fish sale (US\$ / ha)

Profit of aquaculture (US\$ / ha)

Benefit-cost ratio of aquaculture

Fish yield (kg / ha)

Labor productivity (US\$ / hour)

Harvested fish kept for consumption $(\mathrm{kg})$

Deepest pond group (>2 m):

Costs of aquaculture (US\$ / ha)

Revenue from fish sale (US\$ / ha)

Profit of aquaculture (US\$ / ha)

Benefit-cost ratio of aquaculture

Fish yield (kg / ha)

Labor productivity (US\$ / hour)

Harvested fish kept for consumption (kg)

$\begin{aligned}-1242.52 & >2.00 \\ -5411.56 * * & >2.00 \\ -4169.03 & >2.00 \\ -0.89 & >2.00 \\ -2117.55 & >2.00 \\ -8.45 & >2.00 \\ -42.79 * * * & >2.00\end{aligned}$

$-1050.02$

$>2.00$

$-5597.06>2.00$

$-4547.04>2.00$

$-1.05>2.00$

$\begin{array}{lr}-77.84 & 1.90\end{array}$

$\begin{array}{ll}-25.04 & >2.00\end{array}$

$-26.84>2.00$

1650.37

1.00

$\begin{array}{ll}-1374.95 & 1.60\end{array}$

$\begin{array}{ll}-3025.31 & 1.95\end{array}$

$-0.71>2.00$

$41.15 \quad 1.00$

$\begin{array}{ll}114.26 & 1.00\end{array}$

$91.44 \quad 1.00$

Diff. is the difference in mean of the outcome variables between the two groups. Sig. is the statistical significance of the difference in mean using t-test. Standard error used in the t-test is estimated using bootstrapping with 500 repetitions.

$$
* * * \mathrm{p}<0.01, * * \mathrm{p}<0.05, * \mathrm{p}<0.1
$$

